\title{
Beskytter moderat alkoholforbruk mot hjerte-karsykdom?
}

\author{
Inger Stensvold \\ Statens helseundersøkelser, Postboks 8155 Dep, 0033 Oslo
}

\begin{abstract}
SAMMENDRAG
Tre store utenlandske oppfølgingsstudier fra 1994-95 har funnet en U-formet sammenheng mellom selvrapportert alkoholinntak og dødelighet av hjerte-karsykdom. For menn er det vist at tre alkoholenheter (drinker) pr. dag og for kvinner én til to, kan redusere risikoen med opptil 50\%. Det synes videre som om effekten er størst hos eldre personer (over 50 år), og de med minst én viktig koronar risikofaktor. En ny oversiktsartikkel konkluderer med at den gunstige effekten er knyttet til alkoholinnholdet og ikke til andre komponenter for de ulike alkoholtypene. Det er presentert norske spørreskjema fra $1977 \mathrm{og}$ fram til i dag vedrørende alkohol. Disse er av svært ujevn kvalitet, bl.a. uten spørsmål om mengde alkohol eller type, og spørsmålene har variert over tid og fra fylke til fylke. Tverrsnittsdata fra Oppland (1986-88) for menn og kvinner 40-54 år viser en positiv sammenheng mellom alkoholinntak og HDL-kolesterol for begge kjønn og for systolisk blodtrykk for menn, sterkest for drikkere av brennevin og øl. For kvinner er det en U-formet sammenheng mellom drikkere av vin og øl og systolisk blodtrykk. Resultater fra en dødelighetsoppfølging (hjerte-kardød) viser en forhøyet risiko for menn som har drukket øl siste uke og en gunstigere risiko for de som har drukket vin/brennevin siste uke i forhold til de som ikke har svart på alkoholspørsmålene.
\end{abstract}

\section{Stensvold I. Does moderate alcohol consumption protect against cardiovascular disease? Nor J Epidemiol 1996; 6 (1): 69-71.}

\section{ENGLISH SUMMARY}

Three large prospective population studies from 1994-95 have shown a U-shaped relationship between alcohol intake and mortality from cardiovascular disease. For men it was shown that three units a day and for women one to two units can reduce mortality risk with $50 \%$. The effect was stronger in older people (above 50 years) and those at greater risk for coronary heart disease. The conclusion, in a recent review, was that the benefit is from alcohol rather than from other components of each type of drink. Norwegian questionnaires from 1977 to 1995 on alcohol are commented upon. The quality of these questions varies; many do not account for the amount of intake or the type of alcohol, and they have not been identical from screening to screening and between counties. Cross-sectional results from Oppland (1986-88) for men and women aged 40-54 years, indicated a positive relation between alcohol intake and HDL-cholesterol for both sexes, for systolic blood pressure in men, strongest for consumers of spirits and beer. A U-shaped association between intake of wine and beer with systolic blood pressure was seen in women. A follow-up study with cardiovascular death as endpoint indicated a higher risk for men drinking beer during the last week, and a lower risk for those drinking wine/spirits, compared with men not answering the questions about alcohol intake.

\section{INNLEDNING}

Flere avisoppslag i Norge har i den senere tid tatt opp den gunstige effekt av alkohol på hjertet, ved bl.a. å skrive at ett glass rødvin pr. dag forlenger livet! Det er videre mange nyere epidemiologiske undersøkelser som har vist at et moderat forbruk av alkohol har en gunstig effekt på hjerte-karsykdom. Det er vist en Jeller U-formet kurve over sammenhengen mellom alkoholinntak og hjerte-kardødelighet, dvs. at de som har lavest og høyest alkoholinntak har høyest dødelighet.

Det er mange spørsmål som kan stilles i den sammenheng: 
- Hva betyr et moderat alkoholinntak?

- Betyr typen av alkohol noe?

- Har alkohol den samme effekt for kvinner som menn, for unge og gamle?

Jeg vil i det følgende oppsummere noen av de største og nyeste epidemiologiske studiene som har analysert sammenhengen mellom alkoholinntak og hjertekarsykdom og død i oppfølgingsstudier, samt si noe om hvilke norske alkoholdata som finnes ved Statens helseundersøkelser. I tillegg vil jeg presentere noen tverrsnittsdata fra Oppland fylke og en dødelighetsoppfølging fra tre norske fylker.

\section{Måleenheter for alkohol}

I mange epidemiologiske studier brukes ordet "alkoholenheter" for å sammenlikne ulike alkoholtyper og -styrker. I Norge er én alkoholenhet $12-13 \mathrm{~g}$ ren alkohol, i Storbritannia regnes én enhet som 8-9 g og i USA som 13-14 g ren alkohol. Tabell 1 viser ulike typer og mengder av alkohol.

Tabell 1. Alkoholtyper og -mengder, definert som én alkoholenhet

\begin{tabular}{lcccc}
\hline Type & $\begin{array}{c}\text { Mengde } \\
\mathrm{ml} *\end{array}$ & $\begin{array}{c}\text { Alkohol, } \\
\text { volum \% }\end{array}$ & $\begin{array}{c}\text { Alkohol, } \\
\mathrm{g}\end{array}$ & $\begin{array}{c}\text { Mengde (ml) } \\
\text { som inneholder } \\
\text { ca. 60 g alkohol }\end{array}$ \\
\hline Øl (pils) & 350 & 4,5 & 12,5 & 1.700 \\
Vin (rød & 120 & 12,7 & 12,1 & 600 \\
eller hvit) & & 20,0 & 12,7 & 380 \\
Hetvin & 80 & 41,0 & 13,0 & 185 \\
Brennevin & 40 & &
\end{tabular}

* Denne mengden tilsvarer omtrent én alkoholenhet i Norge

I mange land er det enighet om at 6 enheter alkohol pr. dag er et "storforbruk" av alkohol, og dette tilsvarer altså ca. 4 halvlitere med pils eller i underkant av en flaske vin pr. dag. De fleste undersøkelsene viser til et gjennomsnittlig alkoholforbruk pr. uke eller måned, det er ikke gjort forsøk på å differensiere mellom daglig drikking kontra "helgefyll". Jeg skal komme nærmere tilbake til hva som oppfattes som moderat forbruk av alkohol.

\section{INTERNASJONALE EPIDEMIOLOGISKE STUDIER}

En oversiktsartikkel fra 1984 (1) tok for seg foreliggende epidemiologiske studier, herunder 6 casekontroll studier (1976-81) og 7 longitudinelle studier (1977-82) og stilte spørsmålet: «Beskytter moderat alkoholinntak mot hjerteinfarkt?» De fleste studiene viste en negativ sammenheng mellom alkoholinntak opptil 30-60 g pr. dag (3-5 enheter pr. dag) og døde- lighet av hjerteinfarkt. Det ble i studiene tatt hensyn til at avholdsfolk kan være tidligere alkoholikere eller at de kunne ha sluttet å drikke fordi de var syke. Videre ble det korrigert for de vanlige risikofaktorer for hjerteinfarkt, som røyking, kolesterol og blodtrykk.

Nedenfor vil jeg gå litt nærmere inn på 3 nyere oppfølgingsstudier:

\section{British male doctors (2)}

I 1951 svarte 34.439 mannlige britiske leger, født 1900-30, på et spørreskjema om røykevaner, og dette var starten på en oppfølgingsstudie om røyk og dødelighet som har fortsatt i 40 år. I 1978 ble det i tillegg til røyk også spurt om alkoholvaner, og 12.321 leger er med i en 13 års oppfølgingsstudie vedrørende alkohol og dødelighet. $10 \%$ av legene drakk ikke alkohol, mens $16 \%$ drakk 29 eller flere enheter pr. uke (ca. $35 \mathrm{~g}$ eller mer pr. dag).

Det var en U-formet sammenheng mellom totaldød og rapportert alkoholinntak, med den laveste dødelighet for leger som rapporterte at de drakk 8-14 enheter pr. uke. For hele gruppen av menn, både de som hadde nåværende eller tidligere hjerte-karsykdom eller diabetes, hadde de som rapporterte et ukentlig inntak på 15-21 enheter (i gjennomsnitt ca. $100 \mathrm{~g}$ ren alkohol pr. uke) den laveste hjerteinfarktdødeligheten. Den relative risiko i forhold til menn som ikke drakk alkohol var $0,58(0,44-0,75)$, justert for alder og røykevaner. Disse forskjellene i dødelighet var til stede uavhengig av tidligere sykdom, alder (under 75 eller 75 år og eldre) og oppfølgingsperiode (første fem år og siste åtte år).

\section{The Nurses' Health Study (3)}

Den store sykepleierkohorten ble etablert i 1976 da 121.700 kvinnelige sykepleiere, 30-55 år, fylte ut et spørreskjema om kjente eller mulige risikofaktorer for kreft og hjerte-karsykdom. Nye spørreskjema ble sendt inn 2. hvert år og i 1980 ble det også spurt om kostholdsvaner, herunder inntak av alkohol, fordelt på $ø l$, vin og brennevin. Oppfølgingsstudien omfatter 85.709 sykepleiere som er fulgt i 12 år. Av disse svarte $30 \%$ at de ikke drakk alkohol, mens $5 \%$ svarte at de drakk $30 \mathrm{~g}$ eller mer alkohol pr. dag.

Også i denne studien var det en U-formet sammenheng mellom inntak av alkohol og totaldød, med det laveste punkt på ca. 1,5 til 4,9 g alkohol pr. dag (1-3 enheter pr. uke). Sykepleiere som rapporterte et konsum av alkohol som var høyere enn 1,5 g pr. dag, hadde alle en statistisk signifikant lavere dødelighet av hjerteinfarkt enn dem som ikke drakk alkohol. Den relative risiko varierte mellom $0,51(0,36-0,73)$ for inntak på 1,5 til 4,9 $\mathrm{g}$ alkohol pr. dag til 0,59 $(0,35-0,99)$ for inntak på $30 \mathrm{~g}$ eller mer (ca. 17 eller flere enheter pr. uke). I analysene er kvinner med tidligere kjent sykdom (kardiovaskulær, kreft, alkoho- 
lisme) ekskludert, og det er justert for alle kjente risikofaktorer for koronar sykdom.

Separate analyser av sammenhengen mellom type av alkohol og dødelighet ga ingen signifikante forskjeller, men inntak av vin hadde en antydning av større beskyttende effekt. Kvinner med én eller flere risikofaktorer for hjerte-karsykdom (f.eks. høyt blodtrykk eller diabetes, nåværende røykere, høyt kolesterol) og kvinner 50 år og eldre hadde den gunstigste effekten av et lett til moderat alkoholinntak.

\section{Copenhagen city heart study (4)}

I denne danske studien har 6.051 menn og 7.234 kvinner i alder 30-79 år deltatt $i$ en helseunders $ø$ kelse i 1976-78 og har fylt ut et spørreskjema om helse, røykevaner, alkoholinntak m.m. Det ble spurt både om type og mengde alkohol, og dataene er analysert typespesifikt. Dødelighetsoppfølgingen har pågått ut 1988, dvs. 10-12 år. Ca. 10\% av mennene og 29\% av kvinnene drakk ikke alkohol, mens $21 \%$ av mennene drakk 3 eller flere enheter øl pr. dag (35 g alkohol eller mer), mens $6 \%$ av kvinnene drakk én eller flere enheter $ø l$ pr. dag ( $12 \mathrm{~g}$ eller mer). Under $5 \%$ av både menn og kvinner drakk vin eller brennevin daglig.

I dødelighetsanalysene ble personer som drakk mer enn 5 alkoholenheter av én av typene pr. dag ekskludert, og resultatene er justert for alder, kjønn og røykevaner. Figur 1 viser relativ risiko for hjertekardødelighet i relasjon til inntak av vin, øl og brennevin. Risiko er satt lik 1.0 for personer som aldri drakk. For vin er relativ risiko lik $0,44(0,24-0,80)$ for personer som drakk 3 til 5 enheter pr. dag (250 til 420 $\mathrm{g}$ alkohol pr. uke). Også for øl er hjerte-kardødeligheten lavere for de som drikker enn for de som ikke drikker, i høyeste inntaksgruppe er relativ risiko 0,72 $(0,61-0,88)$. For brennevin er det en økende dødelighet med økt inntak, relativ risiko for høyeste inntak er $1,35(1,00-1,83)$. Det ble ikke funnet signifikant effekt av inntekt og utdanning på sammenhengen mellom noen av alkoholtypene og dødelighet.

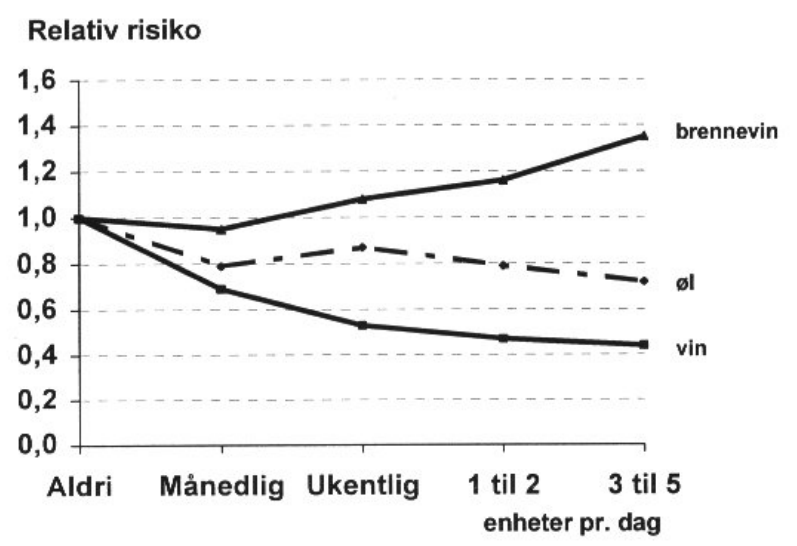

Figur 1. The Copenhagen city heart study (4). Relativ risiko for dødelighet av hjerte-karsykdom i forhold til inntak av brennevin, øl og vin. Menn og kvinner, alder 30-79, fulgt i 11 år.

\section{HAR VI NORSKE DATA?}

\section{Sporreskjemaundersokelser - hva er samlet inn av Statens helseundersokelser?}

I 1973 startet den første hjerte-karundersøkelsen i Finnmark og ble etterfulgt av fylkene Sogn og Fjordane og Oppland. I sistnevnte fylke (1976-77) ble det også delt ut et kostholdsskjema til alle frammøtte, som var utarbeidet av Avdeling for kostholdsforskning, Universitetet i Oslo. Dette ble gjentatt i alle 3 fylkene ved annengangs undersøkelse i 1977-82. Spørsmålet om alkoholvaner var lite omfattende og kan være vanskelig å tolke, se appendix punkt 1 .

Ved 3. gangs hjerte-karundersøkelse (1985-88) var spørsmål om alkoholtype og -mengde også tatt med, men spørsmålene i Finnmark ble formulert forskjellig fra de to andre fylkene, se appendix punkt 2 og 3 (Fordeling av alkoholsvar er gitt i ref. 5).

I tillegg har Statens helseundersøkelser data om alkohol fra flere tilleggsundersøkelser til 40-årings undersøkelsene, i Østfold og Aust-Agder I og II (1985-89), i Troms I (1991), i Finnmark IV og V (1990-93), i Hordaland (1992) samt i den store Helseundersøkelsen i Nord-Trøndelag (1984-86).

Fra og med 1995 er spørsmål om alkohol tatt inn i det ordinære spørreskjema (invitasjonsbrevet) som et ledd i CONOR-prosjektet dvs. ved alle 40-årsundersøkelsene, Tromsøundersøkelsen (1994-95) og den nye helseundersøkelsen i Nord-Trøndelag (1995-97). Spørsmålene er gjengitt i appendix punkt 4 .

\section{Tverrsnittsdata}

Nedenfor presenteres tverrsnittsdata fra Oppland der hjerte-karundersøkelsene ble gjennomført for tredje gang i 1986-88. Prosedyrene for disse var tilsvarende som for første gangs undersøkelse og er beskrevet tidligere (6). Tabell 2 viser fordeling etter alkoholtype og drikkefrekvens blant de som møtte til undersøkelse i Oppland og som besvarte spørsmålet om totalavhold (ja/nei). I alt $11 \%$ av mennene og $27 \%$ av kvinnene svarte at de var totalavholdende. Siste uke hadde $41 \%$ av mennene og $20 \%$ av kvinnene drukket $ø 1,19 \%$ av både menn og kvinner hadde drukket vin og $44 \%$ og $24 \%$ hadde drukket brennevin.

I Tabell 3 er grunnlaget de personer som har besvart at de bare har drukket en av alkoholtypene siste uke (1 eller flere ganger). Gjennomsnittsverdier av ulike risikofaktorer er beregnet. Tallene er ujusterte, men justering for alder ga kun minimale endringer.

For menn er gjennomsnittsnivået av totalkolesterol høyest i brennevinsgruppen og høyere for de som drikker mer enn tre ganger i uka, uansett alkoholtype (ikke vist), enn for de som er totalavholdende. For kvinner derimot er det en klar invers sammenheng mellom alkoholinntak og total kolesterol. 
Tabell 2. Antall personer (45-54 år) fordelt på alkoholinntak, hyppighet og type. Oppland 1986-88.

\begin{tabular}{|c|c|c|c|c|c|c|c|c|}
\hline & \multicolumn{4}{|c|}{$\operatorname{Menn}(\mathrm{n}=10778)$} & \multicolumn{4}{|c|}{ Kvinner $(n=11381)$} \\
\hline & & $\varnothing 1$ & vin & brennevin & & $\varnothing 1$ & vin & brennevin \\
\hline Avhold & 1223 & & & & 3048 & & & \\
\hline Alkohol siste uke: & & & & & & & & \\
\hline ikke & & 6374 & 8628 & 6046 & & 8955 & 9000 & 8472 \\
\hline 1 gang & & 3065 & 1580 & 3648 & & 1865 & 1752 & 2323 \\
\hline $2-3$ ggr & & 1064 & 332 & 880 & & 277 & 312 & 292 \\
\hline$>3$ ggr & & 202 & 37 & 122 & & 38 & 34 & 29 \\
\hline
\end{tabular}

Tabell 3. Gjennomsnittsverdier av ulike risikofaktorer i forhold til alkoholtyper. Menn og kvinner 40-54 år fra Oppland 1984-86. For de tre alkoholtypene, er de personer tatt med som har besvart at de kun har drukket én av alkoholtypene siste uke (1 eller flere ganger).

\begin{tabular}{|c|c|c|c|c|c|c|c|c|}
\hline & \multicolumn{4}{|c|}{ Menn } & \multicolumn{4}{|c|}{ Kvinner } \\
\hline & avhold & $\varnothing 1$ & vin & brennevin & avhold & $\varnothing 1$ & vin & brennevin \\
\hline Antall & 1223 & 1302 & 368 & 1621 & 3048 & 785 & 829 & 1177 \\
\hline $\begin{array}{l}\text { Infarktrisk } \\
\text { (enheter) }\end{array}$ & 22,1 & 24,8 & 21,4 & 30,8 & 4,7 & 3,7 & 3,7 & 5,7 \\
\hline $\begin{array}{l}\text { Totalkolesterol } \\
(\mathrm{mmol} / \mathrm{l})\end{array}$ & 6,23 & 6,20 & 6,19 & 6,37 & 6,36 & 6,02 & 6,03 & 6,23 \\
\hline $\begin{array}{l}\text { HDL-kolesterol } \\
(\mathrm{mmol} / \mathrm{l})\end{array}$ & 1,16 & 1,25 & 1,24 & 1,24 & 1,47 & 1,53 & 1,57 & 1,57 \\
\hline $\begin{array}{l}\text { Triglyserider } \\
(\mathrm{mmol} / \mathrm{l})\end{array}$ & 2,40 & 2,22 & 2,18 & 2,38 & 1,67 & 1,45 & 1,38 & 1,62 \\
\hline $\begin{array}{l}\text { Systolisk blodtrykk } \\
(\mathrm{mmHg})\end{array}$ & 134,2 & 134,5 & 132,9 & 135,7 & 131,8 & 126,9 & 125,2 & 130,0 \\
\hline $\begin{array}{l}\text { Kroppsmasseindeks } \\
\left(\mathrm{kg} / \mathrm{m}^{2}\right)\end{array}$ & 25,7 & 25,2 & 25,3 & 25,7 & 25,6 & 24,3 & 23,8 & 24,5 \\
\hline $\begin{array}{l}\text { Sigaretter pr. dag } \\
\text { (antall) }\end{array}$ & 13,0 & 14,0 & 13,3 & 14,1 & 9,9 & 10,7 & 10,8 & 11,3 \\
\hline
\end{tabular}

Figur 2 viser en positiv sammenheng mellom alkoholinntak og HDL-kolesterol, justert for alder. For menn er HDL-kolesterolnivået ca. $25 \%$ og for kvinner $20 \%$ høyere for personer som drikker alkohol mer enn 3 ganger i uken i forhold til avholdsfolk. Differansen er ca. $0,3 \mathrm{mmol} / 1$ for begge kjønn. Det er små forskjeller mellom alkoholtypene. I en tidligere oppfølgingsstudie med utgangspunkt i resultater fra fylkesundersøkelsene i Oppland, Sogn og Fjordane og Finnmark (1977-82) ble det funnet at en endring på $0,3 \mathrm{mmol} / 1 \mathrm{i}$ HDL-kolesterol for menn og kvinner 40-54 år, tilsvarer en forskjell i infarktdødelighet på ca. $15 \%$ for menn og 30\% for kvinner (7).

Det var en uttalt invers dosesammenheng for triglyserider med ett unntak: brennevinsgruppen for menn. For begge kjønn fantes det laveste nivået av triglyserider $\mathrm{i}$ vingruppen med inntak mer enn tre

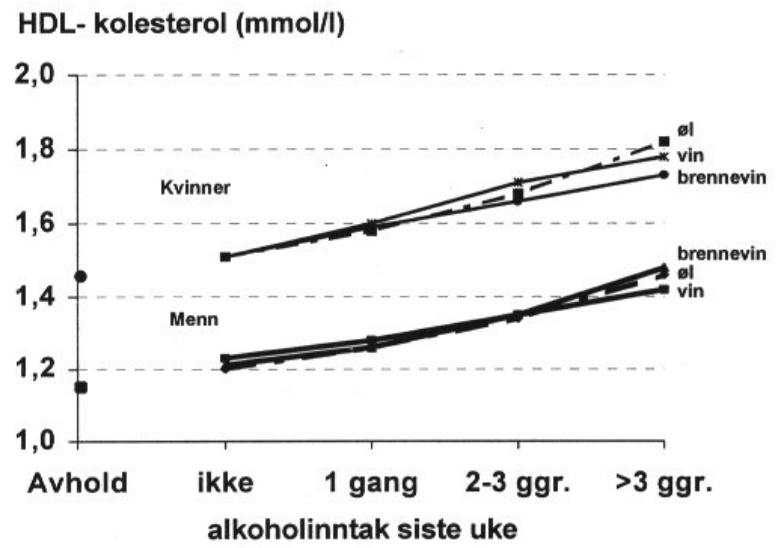

Figur 2. Hjerte-karundersøkelsen i Oppland 1986-88. Gjennomsnittlig HDL-kolesterol, justert for alder, for kvinner og menn (40 - 54 år) pr. oppgitt alkoholinntak siste uke. 
ganger i uka. Sammenliknet med avholdsgruppen var forskjellen $0,43 \mathrm{mmol} / 1$ for menn og $0,49 \mathrm{mmol} / 1$ for kvinner. I oppfølgingsstudien fra fylkesundersøkelsene (1974-78) var triglyserider ingen selvstendig risikofaktor for koronardød blant menn, men derimot blant kvinner (8).

Blant menn stiger gjennomsnittlig systolisk blodtrykk jevnt med økende inntak, men sammenhengen er klart svakere i vingruppen (Figur 3). For kvinner er det en U-formet sammenheng. Hos de som inntar brennevin mer enn tre ganger i uka er gjennomsnittstrykket $4 \mathrm{mmHg}$ høyere enn hos de som drikker vin mer enn tre ganger i uka. I den ovenfor refererte oppfølgingsstudien svarer en forskjell på $4 \mathrm{mmHg} \mathrm{i}$ systolisk blodtrykk til en forskjell i infarktdødelighet på $10-15 \%$ for både menn og kvinner (7). Det bemerkes at blodtrykksnivået er nesten likt for kvinner som drikker brennevin mer enn tre ganger i uka og menn som drikker vin like hyppig.

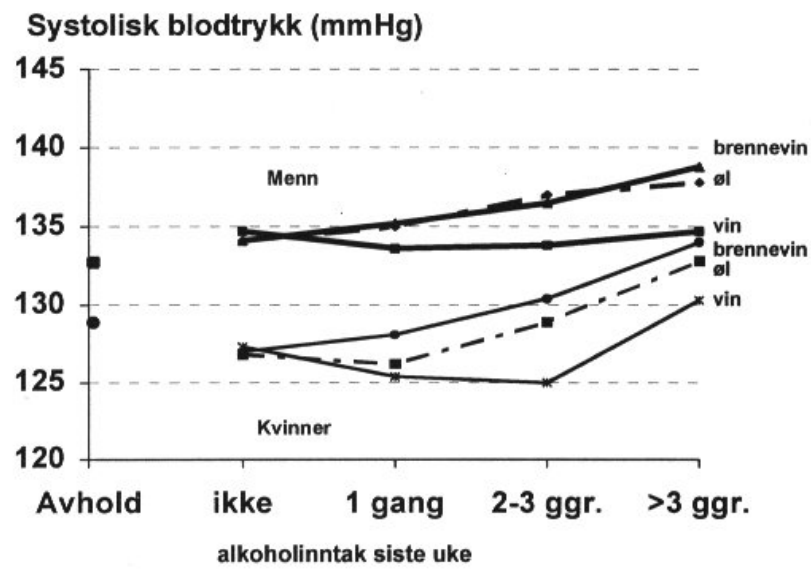

Figur 3. Hjerte-karundersøkelsen i Oppland 1986-88. Gjennomsnittlig systolisk blodtrykk, justert for alder, kroppsmasseindeks og antall sigaretter pr. dag, for kvinner og menn (40-54 år) pr. oppgitt alkoholinntak siste uke.

Sammenhengene mellom alkoholinntak og diastolisk blodtrykk følger samme mønster som for systolisk blodtrykk.

\section{Resultater fra oppfolging av 2. gangs fylkesunder- sokelse - alkohol og hjerte-kardodelighet}

En dødelighetsoppfølging er gjort med utgangspunkt i svarene fra spørsmålene om alkohol ved hjertekarundersøkelsene i de tre fylkene i perioden 1977-83 (Appendix punkt 1). Analysen er kun gjort for menn, fordi få kvinner svarte bekreftende på alkoholforbruk (85\% drakk hverken øl eller vin/brennevin siste uke) og få kvinner døde av koronarsykdom i oppfølgingsperioden på ca. 12 år. Analysen omfatter 18.600 menn, 35-54 år ved undersøkelse II, og uten selvrapportert hjerte-karsykdom eller diabetes. Endepunkt er hjerte-kardød (ICD-9: 390-459). Relativ risiko er estimert ved Cox proportional hazards regresjon.

Av mennene svarte $58 \%$ ikke på noen av alkoholspørsmålene, $13 \%$ svarte «ja» på øl, $16 \%$ «ja» på vin/brennevin og $12 \%$ svarte «ja» på begge spørsmålene. Figur 4 viser de estimerte relative risikoer fra den prospektive analysen. Menn som har drukket vin/brennevin siste uke, har en relativ risiko på $0,8 \mathrm{i}$ forhold til de som ikke har besvart alkoholspørsmålene, tilsvarende for øl er 1,2 og for begge svarene 1,0 .

LDL-kolesterol er beregnet etter Friedewalds formel utfra total kolesterol, HDL-kolesterol og triglyserider (9), og analysene er gjort for to nivåer av LDL-kolesterol (under og over 5,0 mmol/l). Relativ risiko for de ulike alkoholsvarene var ikke forskjellig ved de to nivåene av LDL-kolesterol.

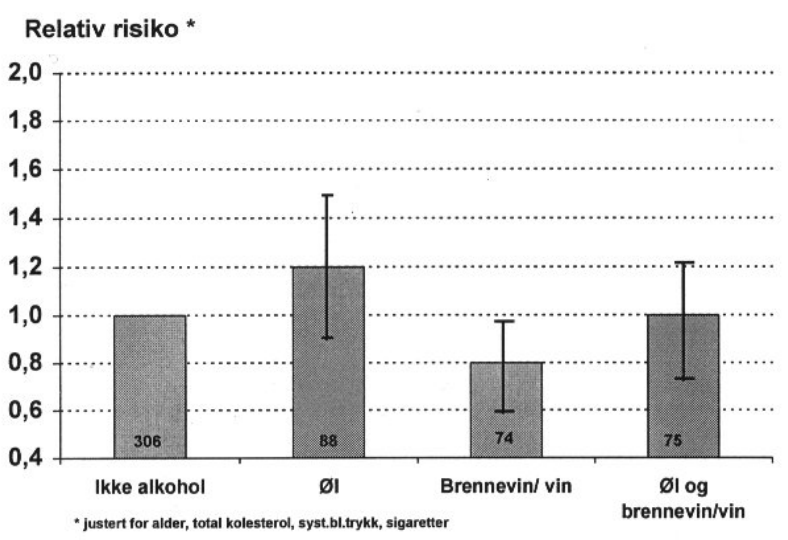

Figur 4. Fylkesundersøkelsene i Norge, menn, 35-54 år $i$ 1977-82, oppfølgingstid: 12,1 år. Relativ risiko for dødelighet av hjerte-karsykdommer i forhold til inntak av alkohol. Tallene angir antall døde i hver alkoholgruppe.

\section{DISKUSJON}

Tre store utenlandske oppfølgingsstudier har funnet en U-formet sammenheng mellom alkoholkonsum og sykelighet/dødelighet av hjerteinfarkt (2-4). Den høyere risiko for de som ikke bruker alkohol har ikke kunnet forklares ved spesiell seleksjon til denne gruppen. Flere andre studier har gitt samme resultat. Muligheten for publikasjonsskjevhet er alltid tilstede, men alle publiserte arbeider gir et svært konsistent resultat. $(1-4,10)$. Det synes som om menn kan drikke noe mer enn kvinner og eldre noe mer enn yngre personer for å "ligge i nederste del av U-formen", som i disse studiene betyr et alkoholinntak på 1-3 enheter (10-35 g alkohol) pr. dag.

Dødelighetsoppfølgingen som her er presentert er såvidt meg bekjent, den første norske oppfølgingsstudien. Spørsmålet om alkohol hadde åpenbare svakheter; blant annet ble det ikke spurt om mengde. 
Det er altså ikke mulig å belyse problemet om Uformet sammenheng og isåfall hvilket inntak som gir lavest risiko. Det finnes imidlertid en tidlig norsk studie som viser at alkoholikere som bor i institusjoner har en høy total dødelighet og overdødelighet av hjerte-karsykdom (11).

Spørsmålet om type skilte ikke på vin og brennevin. Tatt $i$ betrakning at også frekvensen ble registrert etter en meget grov inndeling var det faktisk noe overraskende at det framkom en kontrast. De velkjente risikofaktorer er det justert for, men vi kan ikke utelukke at gruppene skiller seg på faktorer vi ikke har registrert, deriblant dose. I en nylig publisert dansk studie ble det funnet at den negative assosiasjonen mellom alkoholinntak og risiko for hjerteinfarkt var sterkt avhengig av nivået av LDL-kolesterol (12). I den foreliggende norske studien er LDL-kolesterol beregnet på grunnlag av en ikke-fastende blodprøve, hvilket ikke er i overensstemmelse med forutsetningene for beregning etter Friedewalds formel (9). I motsetning til den danske studien, fant vi ingen interaksjon mellom alkoholinntak og LDL-kolesterol, men det kan ikke utelukkes at feilklassifisering av personer i de to nivåene av LDL-kolesterol (under og over $5.0 \mathrm{mmol} / \mathrm{l}) \mathrm{kan}$ ha influert på resultatet.

Den danske studien skilte på både alkolholtype og dose (4). U-formen ble forklart med forskjellig dosesammenheng for de tre alkoholtyper: For brennevin var det risikoøkning med økende mengde, for øl var det ingen sammenheng og for vin var det en invers sammenheng mellom mengde og koronarmortalitet. Konsekvensen ville være at det er andre substanser enn alkohol som skulle gi den observerte effekt. Beskyttende stoffer i rødvin som virker som antioksidanter har vært mye diskutert, spesielt i forbindelse med det såkalt franske paradoks $(13,14)$. På den annen side ble det $\mathrm{i}$ en meta-analyse argumentert for at det var alkohol som gir den beskyttende effekt (15). Små mengder av alkohol har vist en økning i den fibrinolytiske aktivitet (16) og minsket plateaggregering (17). Den forhøyede koronardødeligheten for ølgruppen i den foreliggende studien er ikke konsistent med at en eventuell gunstig effekt går gjennom alkohol. Imidlertid omslutter konfidensintervallet også en svakt gunstig effekt. Den lavere risikoen for vin/brennevinsgruppen er forenlig med både en alkohol- og en antioksidant-hypotese.

I mars 1996 er det i en oversiktsartikkel vurdert tre case-kontroll studier, 12 økologiske og 10 prospektive studier med hensyn på effekt av spesifikk type alkohol og koronar risiko (18). De fleste økologiske studiene støtter hypotesen om at vin har den gunstigste effekt på hjertet, men det er knyttet store metodologiske problemer til slike studier og forfatterne vil ikke trekke konklusjoner utfra disse studiene. De øvrige studiene spriker med hensyn til resultatene for de ulike alkoholtypene og forfatterne konkluderer med at den gunstige effekt av vin, øl og brennevin i hovedsak er knyttet til alkoholinnholdet og ikke andre komponenter for de ulike typene (18).

Tverrsnittssammenhengen med HDL-kolesterol i Oppland er helt lik for de tre typer alkohol og dette er også forenlig med en effekt av alkohol på HDLkolesterol, og ikke overensstemmende med en effekt av en substans som kun finnes i én av alkoholtypene. En oppfølgingsstudie i Norge viste en U- eller Lformet sammenheng mellom HDL-kolesterol og kardiovaskulær dødelighet (7) og dette kan bidra til å forklare en U-formet sammenheng mellom alkoholinntak og koronardød. Resonnementet bygger på at alkoholeffekten medieres via HDL-kolesterol. På den annen side er det andre studier som har rapportert en jevnt avtagende koronardødelighet med økende HDLkolesterol uten antydning til noen terskel (19).

Noen studier har rapportert en positiv sammenheng mellom alkoholkonsum og blodtrykk (20). Imidlertid er det også observert J- eller U-formede sammenhenger og en antagelse går på at alkohol er en vasodilator ved lave doser, men øker blodtrykket fra høyere doser $(21,22)$. I Oppland var det en J-formet sammenheng mellom inntak av vin og systolisk blodtrykk. For de andre typer var det imidlertid en positiv sammenheng. Det kan tenkes at den beskyttende effekt av lavt alkoholinntak er mediert via en gunstig effekt både på blodtrykk og HDL-kolesterol, eller at en eventuell ugunstig effekt på blodtrykket mer enn oppveies av den gunstige effekten på HDL-kolesterol. Det er videre verdt å merke seg det lavere blodtrykket i vingruppen i Oppland sammenlignet med de to andre alkoholtyper. Det kan selvsagt skyldes seleksjonsmekanismer, men det skal bli interessant å se om tilsvarende blir å finne i andre fylker hvor det er stilt spørsmål om både alkoholtype og dose.

Det tidligere nevnte "franske paradokset" har blitt diskutert med utgangspunkt $i$ en økologisk studie (13). Her ble fett fra melkeprodukter og vin relatert til koronardød i 17 land i Europa som rapporterte vinkonsumet. Vin var det eneste næringsstoff utover fett fra melkeprodukter som korrelerte signifikant (inverst) med koronardødelighet. Med utgangspunkt i offisiell salgsstatistikk fra Vinmonolet i Norge, er Spearman korrelasjon mellom registrert omsetning av vin i fylkene og koronardødeligheten i fylkene beregnet (23). Den ble faktisk svakt negativ, men langtfra signifikant. De offisielle salgstall er beheftet med velkjente svakheter (hjemmeproduksjon og smugling), og disse kommer i tillegg til andre begrensninger knyttet til økologiske studier.

Hvilket alkoholkonsum skal man etter dette driste seg til å anbefale i den generelle befolkning? Ulike tidskrifter har i den senere tid, på leder- eller kommentarplass tatt opp temaet om alkohol og helse og hva man skal tilrå $(22,24-26)$. Den norske lægeforening hevder at det er en viktig oppgave for legene å medvirke til en begrensning av befolkningens forbruk av alkohol i det forebyggende og helsefrem- 
mende arbeid. I England har the Royal College of Physicians, Psychiatrics, and General Practitioners i 1995 vurdert grunnlaget på nytt og opprettholdt tidligere "sensible limits" av alkoholinntak på 21 enheter pr. uke for menn og 14 enheter for kvinner (27). Artikkelen fra USA konkluderer med følgende:
"In the absence of alcohol-related illnesses, therefore, a drink - or two - a day still seems safe and advisable from a cardiovascular standpoint" (22). Alkoholens øvrige skadevirkninger må imidlertid være med i vurderingen, før man eventuelt anbefaler et glass vin om dagen for hjertets skyld.

\section{REFERANSER}

1. Marmot MG. Alcohol and coronary heart disease. Int J Epidemiol 1984; 13: 160-7.

2. Doll R, Peto R, Hall E, Wheatley K, Gray R. Mortality in relation to consumption of alcohol: 13 years' observations on male British doctors. Br Med J 1994; 309: 911-8.

3. Fuchs CH, Stampfer MJ, Colditz GA, et al. Alcohol consumption and mortality among women. $N$ Engl $J$ Med 1995; 332: 1245-50.

4. Grønbæk M, Deis A, Sørensen TIA, Becker U, Schnohr P, Jensen G. Mortality associated with moderate intakes of wine, beer, or spirits. Br Med $J$ 1995; 310: 1165-9.

5. Westlund K, Søgaard AJ. Helse, livsstil og levekår i Finnmark. Resultater fra hjerte-karundersøkelsen i 198788. Finnmark III. ISM skriftserie nr.28. Universitetet i Tromsø, 1993.

6. Bjartveit K, Foss OP, Gjervig T, Lund-Larsen PG. The cardiovascular disease study in Norwegian counties. Background and organization. Acta Med Scand 1979; Suppl. 634.

7. Stensvold I. Urdal P, Thürmer H, Tverdal A, Lund-Larsen PG, Foss OP. High-density lipoprotein cholesterol and coronary, cardiovascular and all cause mortality among middle-aged Norwegian men and women. Eur Heart J 1992; 13: 1155-63.

8. Stensvold I, Tverdal A, Urdal P, Graff-Iversen S. Non-fasting triglyceride concentration and mortality from coronary heart disease and any cause in middle aged Norwegian women. Br Med J 1993; 307: 1318-22.

9. Friedewald WT, Levy J, Friedrickson DS. Estimation of the concentration of low density lipoprotein cholesterol in plasma, without use of the preparative ultracentrifuge. Clin Chem 1972; 18: 499-509.

10. Klatsky AL, Armstrong MA, Friedman GD. Alcohol and mortality. Ann Intern Med 1992; 117: 646-54.

11. Sundby P. Alcoholism and mortality. Publ.no.6., National Institute for Alcohol Research. Oslo, Universitetsforlaget, 1967.

12. Hein HO, Suadicani P, Gyntelberg F. Alcohol consumption, serum low density lipoprotein cholesterol concentration, and risk of ischemic heart disease: six year follow up in the Copenhagen male study. $\mathrm{Br} \mathrm{Med} \mathrm{J}$ 1996; 312: 736-41.

13. Renaud S, de Logeril M. Wine, alcohol, platelets and the French paradox for coronary heart disease. Lancet 1992; 339: 1523-6.

14. Frankel EN, Kanner J, German JB, Parks E, Kinsella JE. Inhibiton of oxidation of human low-density lipoprotein by phenolic substances in red wine. Lancet 1993; 341: 454-7.

15. Maclure M. Demonstration of deductive meta-analysis: Ethanol intake and risk of myocardial infarction. Epidemiol Rev 1993; 15: 328-51.

16. Hendriks HF, Veenstra J, Velthuis-te Wierik, Schaafsma G, Kluft C. Effect of dose of alcohol with evening meal on fibrinolytic factors. Br Med J 1994; 308: 1003-6.

17. Meade TW, Ineson JD, Stirling Y. Effects of changes in smoking and other characteristics on clotting factors and the risk of ischaemic heart disease. Lancet 1987; ii: 986-8.

18. Rimm EB, Klatsky A, Grobbee D, Stampfer MJ. Review of moderate alcohol consumption and reduced risk of coronary heart disease: is the effect due to beer, wine, or spirits? Br Med J 1996; 312: 731-6.

19. Gordon DJ, Probstfield JL, Garrison RJ, et al. High-density lipoprotein cholesterol and cardiovascular disease. Four prospective American studies. Circulation 1989; 79: 8-15.

20. Klatsky AL, Friedman GD, Armstrong MA. The relationships between alcoholic beverage use and other traits to blood pressure: a new Kaiser Permanente study. Circulation 1986; 73: 628-36.

21. Criqui MH. Alcohol consumption, blood pressure, lipids, and cardiovascular mortality. Alcoholism: Clinical and experimental research 1986; 10: 564-9.

22. Victor RG, Hansen J. Alcohol and blood pressure - a drink a day.... N Engl J Med 1995; 332: 1782-3.

23. Grytten L (Red.). Rusmidler i Norge 1995: Rusmiddeldirektoratet og Statens institutt for alkohol- og narkotikaforskning. Oslo, 1995.

24. Eldjarn K. Alkohol og helse. Tidsskr Nor Lageforen 1995; 22: 2827. 
25. Jackson R, Beaglehole R. Alcohol consumption guidelines: relative safety vs absolute risks and benefits. Lancet 1995; 346: 716.

26. Pearson TA, Terry P. What to advise patients about drinking alcohol. The clinician's conundrum. JAMA 1994; 272: 967-8.

27. Royal College of Physicians, Royal College of Psychiatrists, Royal College of General Practitioners. Alcohol and the heart in perspective: sensible limits reaffirmed. London: RCP, RCPsych, RCGP, 1995.

\section{APPENDIX: Spørsmål om alkohol i spørreskjema delt ut ved hjerte-karundersøkelser}

\section{Oppland I (1976-78) og II (1981-83), Finnmark II (1977) og Sogn og Fjordane II (1980):}

- Bruker De vin / brennevin i løpet av en uke ?

(1) $\mathrm{Ja}$

- Bruker De øl i løpet av en uke?

(1) Ja

Personer som ikke besvarer spørsmålet, har enten ikke drukket alkohol siste uke, eller ønsker ikke å svare på spørsmålet. Som teller ved beregning av \% som har besvart "ja", er brukt antallet som besvarer spørsmålet om kaffedrikking.

\section{Sogn og Fjordane III (1985) og Oppland III (1986-88):}

- Bruker De noen gang alkoholholdige drikker?

(1) Nei, er totalavholden

(2) $\mathrm{Ja}$

- Har De drukket øl siste uke ?

(1) Har ikke drukket øl siste uke

(2) 1 gang siste uke

(3) 2-3 ganger siste uke

(4) 4 eller flere ganger siste uke

- Tilsvarende, 2 spørsmål til for "brennevin" og "vin".

\section{Finnmark III (1987):}

- Er De totalavholdsmann /-kvinne )
(1) Ja
(2) $\mathrm{Nei}$

Hvis Nei:

- Hvor ofte pleier De å drikke øl ?

(1) Aldri, eller noen få ganger i året

(2) 1-2 ganger i måneden

(3) Omtrent 1 gang i uken

(4) 2-3 ganger i uken

(5) Omtrent hver dag

- Tilsvarende, 2 spørsmål til for "brennevin" og "vin".

\section{CONOR-spørsmål (fra og med 1995):}

- Er du total avholdsmann/-kvinne ?
(1) $\mathrm{Ja}$
(2) Nei

- Hvor ofte i måneden drikker du vanligvis alkohol ? antall ganger

- Hvor mange glass øl, vin eller brennevin drikker du vanligvis i løpet av to uker? glass øl glass vin glass brennevin 